\title{
Sistem Tracking Cahaya Matahari pada Photovoltaic
}

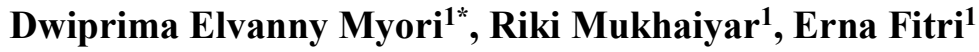 \\ ${ }^{1}$ Jurusan Teknik Elektro, Fakultas Teknik, Universitas Negeri Padang \\ *Corresponding author, e-mail: elvannymyori@gmail.com
}

\begin{abstract}
Abstrak - Umumnya solar cell yang dipasang hanya menghadap satu arah tertentu saja. Gerak semu harian matahari menyebabkan perubahan posisi matahari dari timur ke barat setiap harinya. Perubahan posisi matahari tersebut membuat modul solar cell tidak selalu mendapatkan intensitas cahaya matahari yang maksimal sepanjang hari. Salah satu cara yang dapat dilakukan supaya solar cell mendapatkan intensitas cahaya matahari yang maksimal sepanjang hari adalah dengan menempatkan modul solar cell tegak lurus mengikuti cahaya matahari. Hal tersebut yang melatarbelakangi pembuatan alat tracking cahaya matahari menggunakan komponen Light Dependent Resistor (LDR) sebagai sensor dan motor linear aktuator parabola sebagai penggerak posisi modul solar cell. Cahaya matahari yang mengenai sensor LDR membuat resistansinya berubah sehingga mempengaruhi nilai tegangan yang akan diinformasikan ke analog input mikrokontroller. Mikrokontroller mengolah informasi yang diterima dari sensor LDR dan memberi perintah untuk menggerakkan linear aktuator yang mana akan menggerakkan posisi permukaan modul solar cell dengan dua arah yaitu mengikuti orientasi gerak semu harian matahari dari arah timur ke arah barat. Pada arah timur dan barat masing-masing terdapat sebuah limit switch. Ketika malam hari modul solar cell ini akan kembali bergerak menghadap ke arah Timur dan akan berhenti ketika limit switch Timur aktif. Alat tracking cahaya matahari ini telah dilakukan uji coba. Alat ini telah dapat mengikuti pergerakan matahari dari timur ke barat dengan daya keluaran solar cell dari 8,71 watt mampu ditingkatkan menjadi 12,46 watt dengan konsumsi daya motor sebesar 2,08 watt.
\end{abstract}

Kata kunci : Solar Cell, Light Dependent Resistor, Tracking

Abstract - Generally the solar cell are installed on one direction only. The daily pseudo motion of the sun causes changes of the sun position from east to west everyday. It makes solar cell modules do not always get the maximum intensity of sunlight. One of the solution for this problem is set the position of solar cell module always perpendicular to the sunlight. This problem is the background of solar tracking device manufacture using the Light Dependent Resistor (LDR) components as a sensor and parabolic actuator linear motor as the solar cell module position driver. The sunlight that hits the LDR sensor makes the resistance change so that it affects the voltage that will be informed to the analog input of the microcontroller. The microcontroller processes the information from the LDR sensor and gives the command to move the linear actuator which will move the solar cell module's position in two directions, following the orientation of the sun's daily pseudo motion. In the east and west directions each has a limit switch. The solar cell module will return to facing east at night and will stop when the east limit switch is active. This solar tracking device has been tested. This device has been able to follow the movement of the sun from east to west with 8.71 watts output of solar cell can be increased to 12.46 watts with 2.08 watts motor power consumption.

Keywords : Solar Cell, Light Dependent Resistor, Tracking

This is an open access article distributed under the Creative Commons 4.0 Attribution License

\section{Pendahuluan}

Listrik menjadi komponen utama untuk memenuhi kebutuhan manusia di era globalisasi sekarang. Dapat dikatakan bahwa energi listrik adalah bagian yang sangat penting untuk manusia saat ini. Hampir semua peralatan yang digunakan untuk mempermudah pekerjaan manusia membutuhkan energi listrik, mulai lampu, peralatan rumah tangga, peralatan dalam dunia kesehatan, peralatan produksi, penerbangan hingga militer yang semuanya membutuhkan energi listrik.

Sumber daya alam tak terbarukan seperti bahan 
bakar fosil digunakan untuk memenuhi sebagian besar kebutuhan energi listrik di Indonesia. Penggunaan bahan bakar fosil ini dapat menimbulkan polusi dan tidak ramah lingkungan. Agar kelestarian lingkungan tetap terjaga dan menghemat persediaan sumber daya alam tak terbarukan, maka kita perlu memanfaatkan sumber daya alam yang dapat diperbaharui dan tidak menimbulkan polusi sebagai sumber energi listrik alternatif.

Negara Indonesia adalah negara tropis yang dilalui oleh garis khatulistiwa sehingga mendapatkan sinar matahari sepanjang tahun. Dengan kondisi geografis ini kita dapat memanfaatkan energi matahari tersebut sebagai sumber energi listrik alternatif yang potensial dan ramah lingkungan. Untuk membangkitkan tenaga listrik dari energi matahari ini dibutuhkan suatu komponen semikonduktor yaitu sel surya (solar cell). Pemanfaatan energi matahari dengan mengaplikasikan sel surya sebagai penghasil energi listrik ini disebut dengan teknologi photovoltaic (PV).

Sekarang ini sudah banyak pemanfaatan photovoltaic dalam kehidupan sehari-hari. Energi listrik yang dihasilkan tergantung pada beberapa faktor yaitu bahan pembuat, intensitas cahaya matahari, temperatur dan posisi sel surya terhadap arah datangnya cahaya matahari. Umumnya penampang modul solar cell dipasang menghadap satu arah tertentu. Gerak semu harian matahari menyebabkan matahari mengalami perubahan posisi setiap harinya. Matahari terlihat terbit dari Timur dan tenggelam di Barat, membuat modul solar cell tidak selalu mendapatkan intensitas cahaya yang maksimal sehingga listrik yang dihasilkan juga kurang optimal. Menurut Mostavan [1], "Bila cahaya yang menimpa modul surya berkurang maka hasilnya juga akan menurun. Bila intensitas cahaya berkurang, jumlah foton per detik yang menembus sel juga akan kurang, oleh sebab itu jumlah elektron yang dilepas juga akan berkurang. Ini menyebabkan berkurangnya arus keluaran pada semua tegangan untuk sebuah modul".

Salah satu cara yang dapat dilakukan untuk mengoptimalkan penyerapan energi surya pada photovoltaic adalah dengan memposisikan bidang modul solar cell selalu tegak lurus dengan arah datangnya cahaya matahari sehingga intensitas cahaya yang diterima lebih besar. Maka perlu dibuat suatu alat tracking cahaya matahari dengan penampang yang dapat mengikuti arah datangnya cahaya, sehingga jika ditempatkan modul solar cell di atasnya, energi listrik yang dihasilkan lebih optimal dibandingkan dengan modul solar cell yang menghadap satu arah tertentu saja. Mengamati hal ini, penelitian ini mencoba untuk membuat sistem tracking yang dapat bergerak memposisikan bidang penampangnya mendekati tegak lurus dengan arah datangnya sinar matahari.

Pada sistem tracking cahaya matahari yang dibuat pada penelitian ini menggunakan linear aktuator sebagai penggerak penampang agar mengikuti arah cahaya akibat gerak semu harian matahari yaitu dari Timur ke Barat. Sistem ini bekerja dengan mendeteksi intensitas cahaya menggunakan sensor LDR (Light Dependent Resistor) yang dikirimkan ke mikrokontoller Arduino. Mikrokontroller arduino memproses data yang diterima, kemudian memerintahkan linear aktuator untuk menggerakkan posisi penampang modul solar cell agar mendapatkan intensitas cahaya yang maksimal.

\section{StUdi Pustaka}

\section{A. Photovoltaic}

Kata photovoltaic terdiri dari dua kata yaitu photo dan volta. Photo berarti cahaya (dari bahasa Yunani yaitu phos, photos: cahaya) dan volta (berasal dari nama Alessandro Volta seorang fisikawan italia yang hidup antara tahun 17451827) yang berarti unit tegangan listrik. Kata photovoltaic biasa disingkat dengan PV. Photovoltaic adalah teknologi yang menghasilkan tenaga listrik DC (direct current) dari bahan semikonduktor ketika terpapar oleh foton. Selama cahaya menyinari solar cell (nama untuk individual elemen photovoltaic), maka akan menghasilkan tenaga listrik. Ketika tidak ada cahaya, energi listrik juga berhenti dihasilkan.

Sinar matahari memancarkan gelombang dengan panjang gelombang berbeda-beda dari $250 \mathrm{~nm}$ sampai dengan $2500 \mathrm{~nm}$ berupa ultraviolet, infrared sampai cahaya tampak. Tidak semua sinar langsung cahaya matahari pada atmosfer sampai ke permukaan bumi. Atmosfer melemahkan banyak bagian spektrum cahaya. Misalnya x-ray hampir semuanya diserap sebelum mencapai tanah. Beberapa persen radiasi ultraviolet juga disaring oleh atmosfer, beberapa dipantulkan kembali ke angkasa dan beberapa bagian lagi tersebar di atmosfer yang membuat langit terlihat biru.

Intensitas cahaya matahari yang sampai ke tanah melemah karena sinar matahari mendekati horizon dan terdapat lebih banyak atmosfer atau massa udara yang akan ditembus. Atmosfer adalah penyerap yang kuat yang dapat mengurangi energi yang sampai ke bumi sebesar $50 \%$ atau lebih. 
Intensitas puncak sinar matahari di permukaan bumi Sekitar $1 \mathrm{~kW} / \mathrm{m}^{2}$. Namun, tidak semua bagian bumiMendapatkan jumlah sinar matahari rata-rata yang sama sepanjang tahun. Ketika sinar matahari yang terdiri atas foton jatuh pada permukaan solar cell, maka foton tersebut akan diserap, dipantulkan dan dilewatkan begitu saja dan hanya foton dengan tingkat energi tertentu yang akan membebaskan elektron dari ikatan atomnya, sehingga mengalirlah arus listrik. Untuk membebaskan elektron dari ikatan kovalennya, energi foton harus sedikit lebih besar atau di atas band gap. Jika foton terlalu besar dari band gap, maka sisa energi tersebut akan diubah dalam bentuk panas pada solar cell.

Secara sederhana cara kerja solar cell dimodelkan dengan konsep pn junction yang terdiri dari persambungan bahan semikonduktor bertipe $\mathrm{p}$ dan $\mathrm{n}$ (pn junction semikonduktor) yang apabila terkena sinar matahari akan terjadi aliran elektron. Struktur lapisan solar cell ditunjukkan oleh gambar 1.

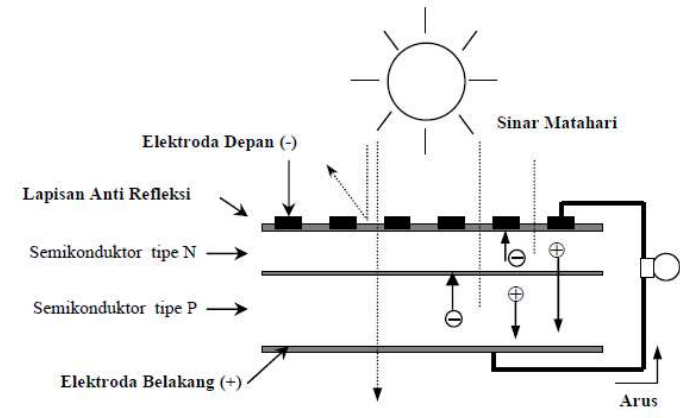

Gambar 1. Struktur lapisan solar cell [2]

Solar cell terbuat dari material semikonduktor yang memiliki ikatan elektron lemah yang menempati pita energi yang disebut valence band. Ketika energi melebihi ambang batas yang dinamakan band gap energy diaplikasikan ke elektron valensi, ikatan akan rusak dan beberapa elektron bebas untuk bergerak dalam ikatan energi baru yang dinamakan conduction band yang dapat menyalurkan listrik melalui material tersebut. Kemudian elektron bebas pada conduction band akan dipisahkan dari valence band oleh band gap (diukur dalam satuan elektron volt atau $\mathrm{eV}$ ). Energi yang dibutuhkan untuk membebaskan elektron ini dipenuhi oleh foton yang merupakan partikel cahaya. Ketika solar cell terpapar cahaya matahari, foton akan menabrak elektron valensi, merusak ikatan dan mendorong mereka ke conduction band. Disana terdapat sebuah kontak selektif khusus yang mengumpulkan conduction band elektron, menggerakkan elektron tersebut ke rangkaian eksternal. Elektron akan kehilangan energi mereka dan dikembalikan ke solar cell melalui kontak selektif ke dua, yang mengembalikan mereka ke valence band dengan energi yang sama ketika pertama kali. Perpindahan elektron pada rangkaian eksternal inilah yang dinamakan sebagai arus listrik.

Parameter solar cell yang paling berpengaruh pada kurva karakteristik arus-tegangan yaitu arus hubung singkat dan tegangan hubungan terbuka untuk parameter internal, sedangkan paramater eksternalnya meliputi suhu dan radiasi cahaya matahari.

\section{B. Sistem Tracking Cahaya Matahari}

Sistem tracking cahaya matahari adalah sebuah kesatuan komponen atau elemen yang digabungkan menjadi satu untuk mengontrol posisi alat sistem tracking dengan tujuan mengusahakan permukaan modul solar cell selalu menghadap arah datangnya cahaya matahari. Sistem tracking cahaya matahari ada beberapa jenis dan dapat diklasifikasikan berdasarkan beberapa kriteria [3]. Klasifikasi pertama dapat dibuat berdasarkan jumlah sumbu putaran.

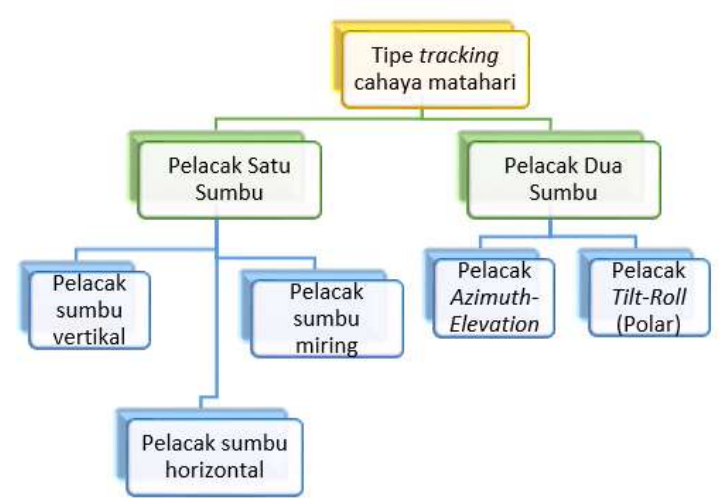

Gambar 2. Tipe solar tracking berdasarkan sumbu putaran [4].

Pada klasifikasi ini sistem tracking cahaya matahari dibedakan menjadi dua yaitu satu sumbu dan dua sumbu. Sistem tracking satu sumbu adalah metode dimana modul solar cell menjejak cahaya matahari dari timur ke barat menggunakan satu titik poros, sedangkan sistem tracking dua sumbu menggunakan dua titik poros untuk menjejak cahaya matahari dari timur ke barat dan dari utara ke selatan. Sistem tracking satu sumbu terbagi lagi menjadi tiga jenis yaitu sumbu vertikal, sumbu horizontal dan sumbu miring. Sedangkan sistem tracking dua sumbu ada dua jenis yaitu azimuthelevation dan tilt-roll.

Klasifikasi lain dari sistem tracking cahaya matahari dapat dibuat berdasarkan tipe orientasi. 
Berdasarkan kriteria ini kita dapat mengidentifikasi sistem tracking cahaya matahari berdasarkan pada lintasan matahari yang telah dihitung sebelumnya dan orientasi on-line yang bereaksi terhadap cahaya matahari secara langsung.
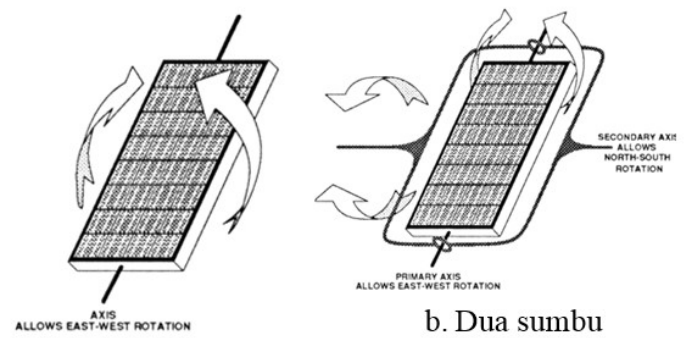

a. Satu sumbu

Gambar 3. Sistem tracking satu sumbu dan dua sumbu [5]

Dalam penelitian ini digunakan sistem tracking satu sumbu karena sistem tracking cahaya matahari mempunyai bagian penggerak dan sistem kontrol yang memerlukan biaya tinggi, maka sistem tracking satu sumbu menjadi solusi terbaik untuk solar cell berukuran kecil.

\section{METODE}

A. Perancangan Alat

Pada bagian ini akan dijelaskan mengenai blok diagram, prinsip kerja, serta perancangan alat.

\section{Blok Diagram}

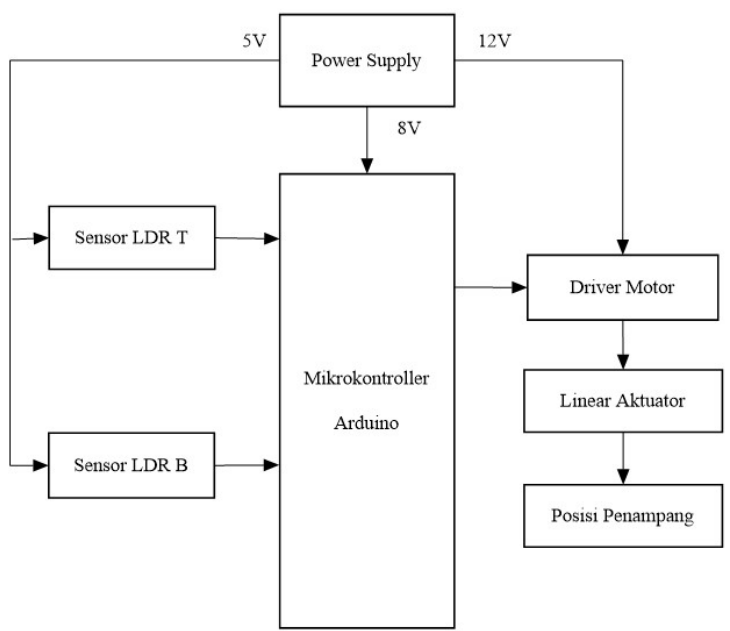

Gambar 4. Blok Diagram

Berikut ini penjelasan masing-masing blok diagram diatas:

a. Power supply digunakan untuk menyuplai daya untuk mikrokontroller arduino, driver motor dan sensor LDR dengan tegangan masing-masing $8 \mathrm{~V}, 12 \mathrm{~V}$ dan $5 \mathrm{~V}$

b. Sensor LDR T digunakan untuk mendeteksi cahaya yang datang dari arah Timur.

c. Sensor LDR B digunakan untuk mendeteksi cahaya matahari yang datang dari arah Barat.

d. Mikrokontroller Arduino digunakan untuk mengontrol pergerakanlinear aktuator berdasarkan data yang diperoleh dari sensor LDR T dan dan LDR B.

e. Linear Aktuator, digunakan untuk memposisikan permukaanmodul solar cellagar tegak lurus dengan arah datangnya cahaya.

f. Driver motor, digunakan untuk mengendalikan putaran linear aktuator berdasarkan instruksi dari mikrokontroller.

g. Posisi penampang merupakan posisi permukaan modul solar cell terhadap cahaya matahari.

\section{Prinsip Kerja Alat}

Sistem tracking cahaya matahari yang dibuat pada penelitian ini adalah jenis tracking single axis pada sumbu horizontal menggunakan rangkaian kontrol dan pemrograman mikrokontroller Arduino sebagai pusat pengolah data yang di dapat melalui sensor LDR. Cahaya matahari yang mengenai sensor LDR membuat resistansinya berubah sehingga mempengaruhi nilai tegangan yang akan diinformasikan ke analog input mikrokontroller.

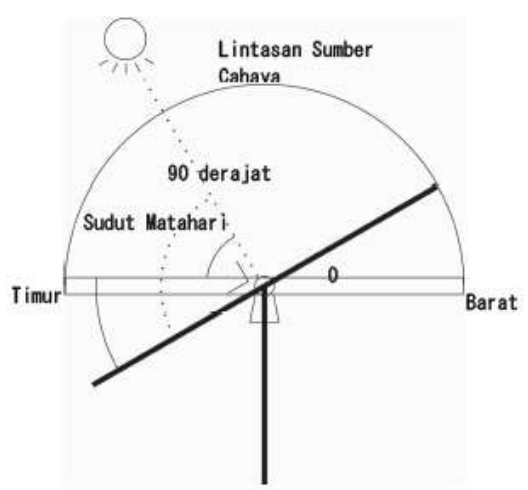

Gambar 5. Pergerakan tracking terhadap posisi matahari

Mikrokontroller mengolah informasi yang diterima dari sensor LDR dan memberi perintah untuk menggerakkan linear aktuator yang mana akan menggerakkan posisi permukaan modul solar cell dengan dua arah yaitu mengikuti orientasi gerak semu harian matahari dari arah Timur ke arah Barat. Pada arah Timur dan Barat masing-masing terdapat sebuah limit switch untuk memberi batas pergerakan, sehingga apabila salah satu limit 
switch itu aktif artinya sudah sampai pada batas maksimal dan tidak dapat melanjutkan pergerakan ke arah tersebut. Ketika malam hari maka modul solar cell ini akan kembali bergerak menghadap ke arah Timur dan akan berhenti ketika limit switch Timur aktif.

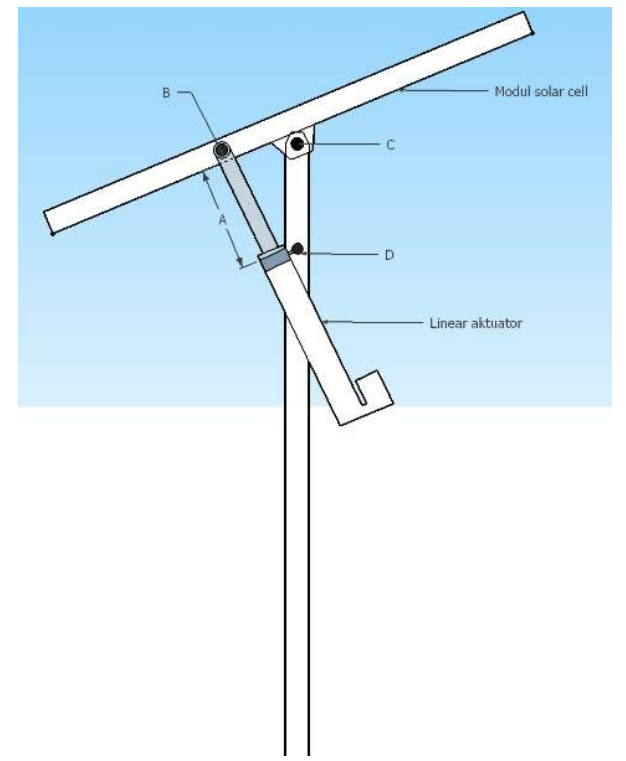

Gambar 6. Mekanisme pergerakan

Modul solar cell digerakkan oleh linear aktuator dengan cara menambah atau mengurangi panjang lengan A sehingga salah satu sisi modul solar cell akan terdorong ke atas apabila lengan memanjang dan akan tertarik ke bawah apabila panjang lengan di kurangi. Pada titik B, C dan D digunakan baut agar dapat berputar saat terjadi perubahan panjang pada lengan A.

\section{Perancangan Hardware}

Perancangan hardware pada penelitian ini meliputi perancangan konstruksi alat serta perancangan rangkaian elektronik. Berikut akan dijelaskan masing-masing bagian perancangan mekanik alat berdasarkan gambar 7

a. Tiang besi penyangga. Tiang penyangga dengan 4 kaki menggunakan besi siku dan tiang bagian atasnya menggunakan besi berbentuk persegi.

b. Linear Aktuator. Linear aktuator digunakan sebagai penggerak posisi modul solar cell. Linear aktuator yang digunakan adalah yang biasa digunakan sebagai aktuator parabola yaitu Venus mini plus 12" dengan spesifikasi tegangan input maksimal 36VDC. Gambar 8 adalah skematik linear aktuator yang akan digunakan.

c. Sensor. Sensor ditempatkan sejajar dengan modul sel surya yaitu sensor LDR T untuk mendeteksi cahaya yang datang dari arah Timur dan LDR B untuk mendeteksi cahaya yang datang dari arah Barat.

d. Limit switch. Digunakan 2 buah limit switch yaitu limit switch $\mathrm{T}$ untuk batas gerakan ke arah timur dan limit switch B untuk batas gerakan ke arah barat.

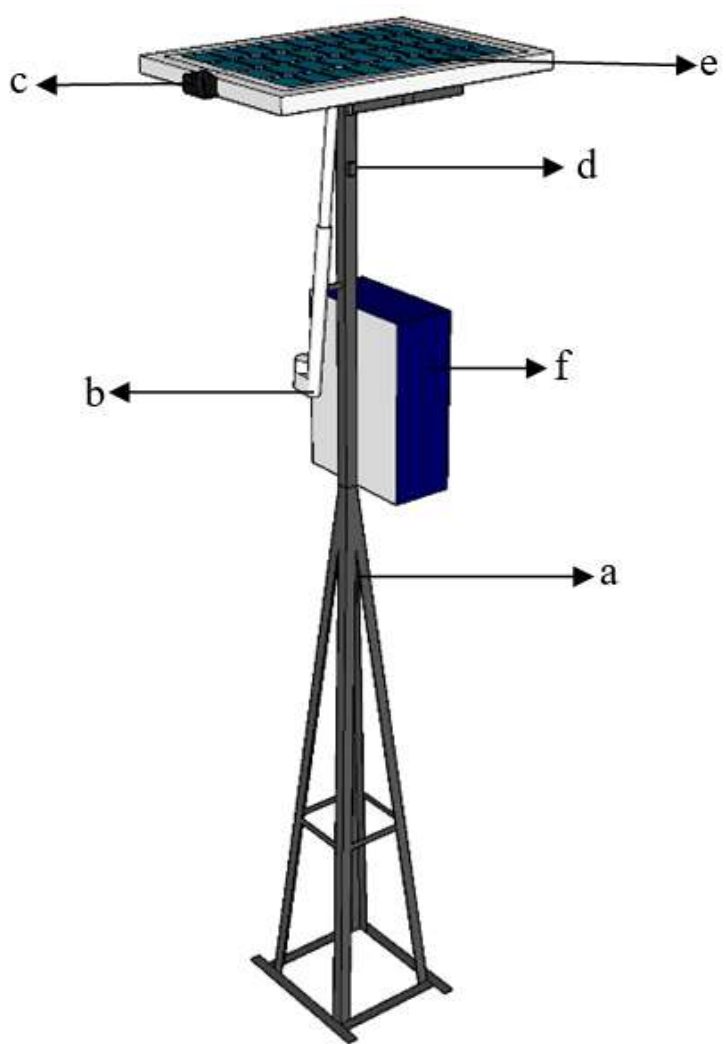

Gambar 7. Rancangan Konstruksi Alat

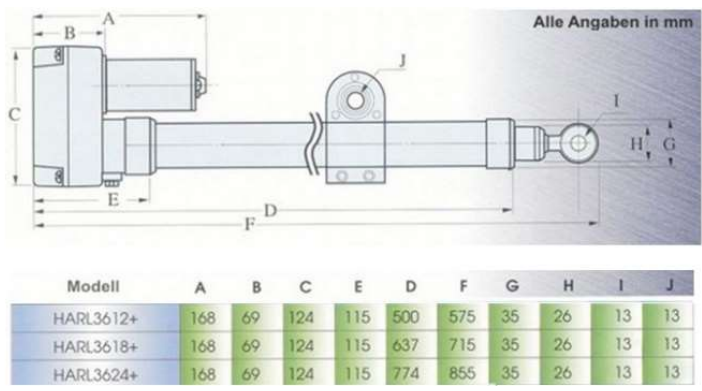

Gambar 8. Skematik Linear actuator

e. Modul Solar Cell. Modul solar cell ditempatkan di atas penyangga yang akan bergerak mengikuti arah datangnya cahaya matahari. Modul solar cell yang digunakan adalah jenis polykristallin dengan spesifikasi yang dapat dilihat pada tabel 1 . 
Tabel 1. Spesifikasi modul solar cell

\begin{tabular}{|l|l|}
\hline Model & SP-20-P36 \\
\hline $\begin{array}{l}\text { Rated Power } \\
\text { (pmax) }\end{array}$ & $20 \mathrm{~W}$ \\
\hline $\begin{array}{l}\text { Voltage at } \\
\text { pmax (Vmp) }\end{array}$ & $17.8 \mathrm{~V}$ \\
\hline $\begin{array}{l}\text { Current at } \\
\text { pmax (Imp) }\end{array}$ & $1.13 \mathrm{~A}$ \\
\hline $\begin{array}{l}\text { Open Circuit } \\
\text { Voltage }\end{array}$ & $21.6 \mathrm{~V}$ \\
\hline $\begin{array}{l}\text { Short Circuit } \\
\text { Current }\end{array}$ & $1.3 \mathrm{~A}$ \\
\hline Size & $490 * 350 * 25 \mathrm{~mm}$ \\
\hline Weight & $1.82 \mathrm{Kg}$ \\
\hline
\end{tabular}

f. Box panel Box panel digunakan untuk meletakkan komponen kontrol untuk alat tracking cahaya matahari.

\section{Flowchart Sistem}

Flowchart merupakan pemetaan urutan instruksi program yang menunjukkan mekanisme kerja dari suatu sistem yang diwakilkan oleh simbol-simbol yang sudah disepakati masing-masing makna dan kegunaannya. Flowchart sistem alat ini seperti digambarkan pada Gambar 9.

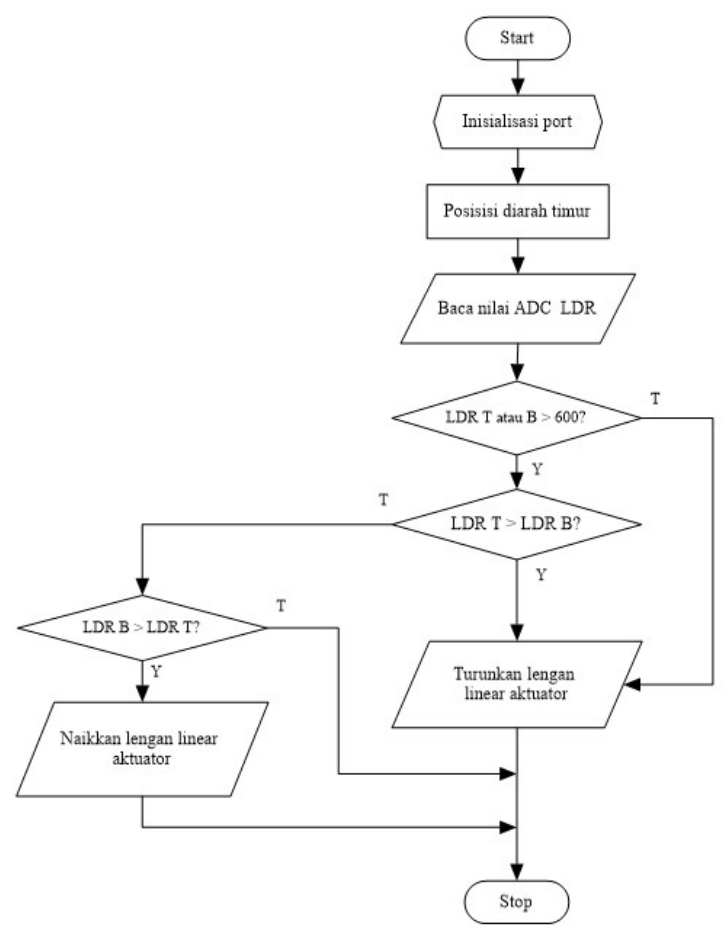

Gambar 9. Flowchart sistem

\section{Hasil dan Pembahasan}

\section{A. Kemiringan Modul Solar Cell terhadap Matahari}

Pengujian kemiringan modul solar cell terhadap posisi matahari adalah pengujian yang dilakukan untuk mengetahui kemampuan alat tracking cahaya matahari untuk mengarahkan permukaan modul solar cell tegak lurus (membentuk sudut $90^{\circ}$ ) dengan sudut datang cahaya matahari. Pengujian ketepatan posisi modul solar cell dengan matahari ini dilakukan dengan mengukur sudut kemiringan permukaan modul solar cell dan sudut datang matahari terhadap solar cell menggunakan busur derajat.

Tabel 2. Hasil pengujian sudut datang matahari dan posisi solar cell

\begin{tabular}{|c|c|c|c|c|c|c|}
\hline \multirow[b]{2}{*}{ Jam } & \multicolumn{2}{|c|}{ Hari ke-1 } & \multicolumn{2}{|c|}{ Hari ke-2 } & \multicolumn{2}{|c|}{ Hari ke-3 } \\
\hline & $\begin{array}{c}\text { Sudut } \\
\text { datang } \\
\text { Mataha } \\
\text { ri }\end{array}$ & $\begin{array}{c}\text { Kemiri } \\
\text { ngan } \\
\text { Solar } \\
\text { cell }\end{array}$ & $\begin{array}{c}\text { Sudut } \\
\text { datang } \\
\text { Mataha } \\
\text { ri }\end{array}$ & $\begin{array}{c}\text { Kemiri } \\
\text { ngan } \\
\text { Solar } \\
\text { cell }\end{array}$ & $\begin{array}{c}\text { Sudut } \\
\text { datang } \\
\text { Matah } \\
\text { ri }\end{array}$ & $\begin{array}{c}\text { Kemiri } \\
\text { ngan } \\
\text { Solar } \\
\text { cell }\end{array}$ \\
\hline 06.00 & - & $35^{\circ}$ & - & $35^{\circ}$ & - & $35^{\circ}$ \\
\hline 07.00 & - & $35^{\circ}$ & - & $35^{\circ}$ & - & $35^{\circ}$ \\
\hline 08.00 & $80^{\circ}$ & $35^{\circ}$ & $75^{\circ}$ & $35^{\circ}$ & $80^{\circ}$ & $40^{\circ}$ \\
\hline 09.00 & $90^{\circ}$ & $35^{\circ}$ & $85^{\circ}$ & $35^{\circ}$ & $90^{\circ}$ & $40^{\circ}$ \\
\hline 10.00 & $90^{\circ}$ & $40^{\circ}$ & $95^{\circ}$ & $45^{\circ}$ & $85^{\circ}$ & $45^{\circ}$ \\
\hline 11.00 & $95^{\circ}$ & $55^{\circ}$ & $95^{\circ}$ & $65^{\circ}$ & $95^{\circ}$ & $65^{\circ}$ \\
\hline 12.00 & $95^{\circ}$ & $70^{\circ}$ & $105^{\circ}$ & $75^{\circ}$ & $95^{\circ}$ & $80^{\circ}$ \\
\hline 13.00 & $80^{\circ}$ & $80^{\circ}$ & $100^{\circ}$ & $90^{\circ}$ & $100^{\circ}$ & $95^{\circ}$ \\
\hline 14.00 & $90^{\circ}$ & $105^{\circ}$ & $100^{\circ}$ & $105^{\circ}$ & $90^{\circ}$ & $110^{\circ}$ \\
\hline 15.00 & $100^{\circ}$ & $120^{\circ}$ & $95^{\circ}$ & $120^{\circ}$ & $95^{\circ}$ & $120^{\circ}$ \\
\hline 16.00 & $100^{\circ}$ & $130^{\circ}$ & $95^{\circ}$ & $135^{\circ}$ & $95^{\circ}$ & $130^{\circ}$ \\
\hline 17.00 & - & $130^{\circ}$ & - & $135^{\circ}$ & - & $135^{\circ}$ \\
\hline 18.00 & - & $35^{\circ}$ & - & $35^{\circ}$ & - & $35^{\circ}$ \\
\hline
\end{tabular}

Tabel 3. Hasil perhitungan rata-rata sudut datang matahari

\begin{tabular}{|c|c|c|c|}
\hline Jam & $\begin{array}{c}\text { Rata-rata } \\
\text { sudut datang } \\
\text { matahari }\end{array}$ & $\begin{array}{c}\text { Besar } \\
\text { penyimpangan } \\
\text { dari posisi } 90^{\circ}\end{array}$ & $\begin{array}{c}\text { Rata-rata } \\
\text { kemiringan } \\
\text { solar cell }\end{array}$ \\
\hline 06.00 & - & - & $35^{\circ}$ \\
\hline 07.00 & - & - & $35^{\circ}$ \\
\hline 08.00 & $78,33^{\circ}$ & $11,67^{\circ}$ & $36,66^{\circ}$ \\
\hline 09.00 & $88,33^{\circ}$ & $1,67^{\circ}$ & $36,66^{\circ}$ \\
\hline 10.00 & $90^{\circ}$ & $0^{\circ}$ & $45^{\circ}$ \\
\hline 11.00 & $95^{\circ}$ & $5^{\circ}$ & $61,66^{\circ}$ \\
\hline 12.00 & $93,33^{\circ}$ & $3,33^{\circ}$ & $75^{\circ}$ \\
\hline 13.00 & $93,33^{\circ}$ & $3,33^{\circ}$ & $88,33^{\circ}$ \\
\hline 14.00 & $93,33^{\circ}$ & $3,33^{\circ}$ & $106,66^{\circ}$ \\
\hline 15.00 & $96,66^{\circ}$ & $6,66^{\circ}$ & $120^{\circ}$ \\
\hline 16.00 & $96,66^{\circ}$ & $6,66^{\circ}$ & $131,66^{\circ}$ \\
\hline 17.00 & - & - & $133,33^{\circ}$ \\
\hline 18.00 & - & - & $35^{\circ}$ \\
\hline
\end{tabular}


B. Hasil keluaran modul solar cell dengan alat tracking cahaya matahari

Pengambilan data hasil keluaran modul solar cell ini dilakukanpada jam 06.00 sampai dengan jam 18.00 selama 3 hari. Alat yang digunakan dalam pengukukuran keluaran modul solar cell ini adalah multimeter. Pengukuran ini dilakukan dengan cara mengukur tegangan hubung terbuka (Voc) dan arus hubung singkat (Isc) yang dilakukan di ruang terbuka.

Tabel 4. Hasil pengukuran keluaran solar cell dengan sistem tracking

\begin{tabular}{|c|c|c|c|c|c|c|}
\hline \multirow{2}{*}{ Jam } & \multicolumn{2}{|c|}{ Hari ke-1 } & \multicolumn{2}{c|}{ Hari ke-2 } & \multicolumn{2}{|c|}{ Hari ke-3 } \\
\cline { 2 - 7 } & $\begin{array}{c}\text { Voc } \\
(\mathrm{V})\end{array}$ & $\begin{array}{c}\text { Isc } \\
(\mathrm{A})\end{array}$ & $\begin{array}{c}\text { Voc } \\
(\mathrm{V})\end{array}$ & $\begin{array}{c}\text { Isc } \\
(\mathrm{A})\end{array}$ & $\begin{array}{c}\text { Voc } \\
(\mathrm{V})\end{array}$ & $\begin{array}{c}\text { Isc } \\
(\mathrm{A})\end{array}$ \\
\hline 06.00 & 6,86 & 0 & 6,21 & 0 & 4,04 & 0 \\
\hline 07.00 & 18,79 & 0,08 & 18,54 & 0,05 & 18,84 & 0,06 \\
\hline 08.00 & 20,5 & 0,75 & 20,4 & 0,71 & 20,1 & 0,76 \\
\hline 09.00 & 20 & 0,9 & 20 & 0,87 & 19,99 & 0,91 \\
\hline 10.00 & 19,9 & 1,01 & 19,8 & 0,97 & 18,83 & 0,95 \\
\hline 11.00 & 19,9 & 1,04 & 20 & 0,99 & 19,99 & 0,98 \\
\hline 12.00 & 19,8 & 1,07 & 19,9 & 1 & 19,84 & 1 \\
\hline 13.00 & 20,1 & 0,95 & 19,9 & 0,99 & 19,81 & 0,99 \\
\hline 14.00 & 20 & 0,9 & 19,8 & 0,98 & 19,76 & 0,86 \\
\hline 15.00 & 19,93 & 0,86 & 19,86 & 0,87 & 19,7 & 0,87 \\
\hline 16.00 & 19,94 & 0,78 & 19,8 & 0,88 & 19,87 & 0,85 \\
\hline 17.00 & 17,95 & 0,06 & 18,22 & 0,08 & 17,65 & 0,07 \\
\hline 18.00 & 16,6 & 0,02 & 16,47 & 0,02 & 16,9 & 0,04 \\
\hline
\end{tabular}

Tabel 5. Hasil perhitungan nilai rata-rata Voc dan Isc dan daya

\begin{tabular}{|c|c|c|c|}
\hline Jam & $\begin{array}{c}\text { Voc Rata- } \\
\text { rata (Volt) }\end{array}$ & $\begin{array}{c}\text { Isc Rata- } \\
\text { rata } \\
\text { (Ampere) }\end{array}$ & $\begin{array}{c}\text { Daya } \\
\text { (Watt) }\end{array}$ \\
\hline 06.00 & 5,7 & 0 & 0 \\
\hline 07.00 & 18,72 & 0,063 & 1,17 \\
\hline 08.00 & 20,33 & 0,74 & 15,04 \\
\hline 09.00 & 19,99 & 0,89 & 17,79 \\
\hline 10.00 & 19,51 & 0,97 & 18,92 \\
\hline 11.00 & 19,96 & 1 & 19,96 \\
\hline 12.00 & 19,84 & 1,02 & 20,23 \\
\hline 13.00 & 19,93 & 0,97 & 19,33 \\
\hline 14.00 & 19,85 & 0,91 & 18,06 \\
\hline 15.00 & 19,83 & 0,86 & 17,05 \\
\hline 16.00 & 19,83 & 0,83 & 16,45 \\
\hline 17.00 & 17,94 & 0,21 & 3,76 \\
\hline 18.00 & 16,65 & 0,02 & 0,33 \\
\hline
\end{tabular}

Berdasarkan table 5 dapat dihitung nilai ratarata daya yang dihasilkan dalam satu hari yaitu 12,46 watt.

C. Hasil keluaran modul solar cell tanpa tracking Hasil keluaran modul solar cell tanpa tracking dilakukan dengan memposisikan permukaan modul solar cell tetap pada posisi $90^{\circ}$ kemudian dilakukan pengukuran nilai Voc dan Isc yang dihasilkan.

Tabel 6. Nilai Voc, Isc dan daya tanpa tracking

\begin{tabular}{|c|c|c|c|}
\hline Jam & Voc (Volt) & Isc (A) & $\begin{array}{c}\text { Daya } \\
\text { (Watt) }\end{array}$ \\
\hline 06.00 & 3,51 & 0 & 0 \\
\hline 07.00 & 17,7 & 0,03 & 0,53 \\
\hline 08.00 & 19,8 & 0,36 & 7,12 \\
\hline 09.00 & 19,2 & 0,6 & 11,52 \\
\hline 10.00 & 19,2 & 0,66 & 12,67 \\
\hline 11.00 & 19,99 & 0,96 & 19,19 \\
\hline 12.00 & 19,6 & 1,01 & 19,79 \\
\hline 13.00 & 19,5 & 0,78 & 15,21 \\
\hline 14.00 & 19,5 & 0,59 & 11,5 \\
\hline 15.00 & 19,6 & 0,52 & 10,19 \\
\hline 16.00 & 18,7 & 0,16 & 2,99 \\
\hline 17.00 & 18,6 & 0,13 & 2,41 \\
\hline 18.00 & 15,2 & 0,01 & 0,15 \\
\hline
\end{tabular}

Berdasarkan tabel di atas dihitung nilai rata-rata daya yang dihasilkan dalam satu hari yaitu 8,71 watt. D. Analisis efektifitas penggunaan tracking dan
tanpa tracking

Analisis efektifitas penggunaan tracking dan tanpa tracking ini dilakukan untuk mengetahui seberapa efektif alat ini mampu meningkatkan daya yang dihasilkan oleh solar cell. Perbandingn nilai Voc, Isc dan daya yang dihasilkan pada saat menggunakan sistem tracking dan tanpa tracking dapat dilihat pada grafik Gambar 10, 11 dan 12.

Berdasarkan grafik diatas dapat terlihat bahwa penggunaan tracking tidak begitu mempengaruhi nilai tegangan, tetapi lebih meningkatkan nilai Arus sehingga daya yang dihasilkan juga lebih meningkat. Berdasarkan pembahasan sebelumnya telah dihitung nilai daya yang dihasilkan tanpa tracking adalah 8,71 Watt, sedangkan dengan menggunakan alat tracking meningkat menjadi 12,46 Watt. Terdapat peningkatan sebesar 3,75 Watt kemudian dikurangi dengan konsumsi daya untuk motor sebesar 2,08 Watt sehingga 
penggunaan alat tracking ini dapat meningkatkan daya keluaran solar cell sebesar 1,67 Watt.

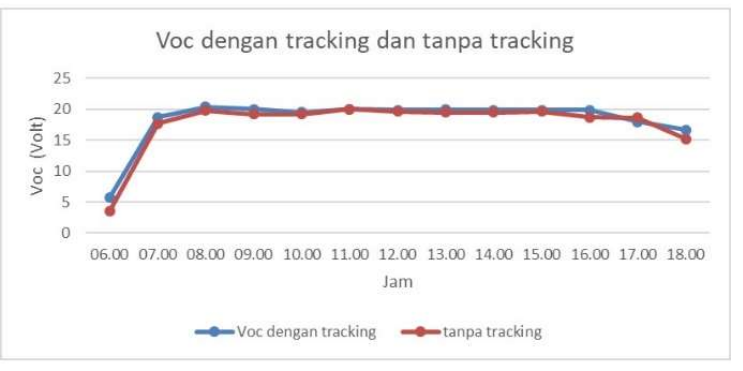

Gambar 10. Grafik perbandingan nilai Voc dengan tracking dan tanpa tracking

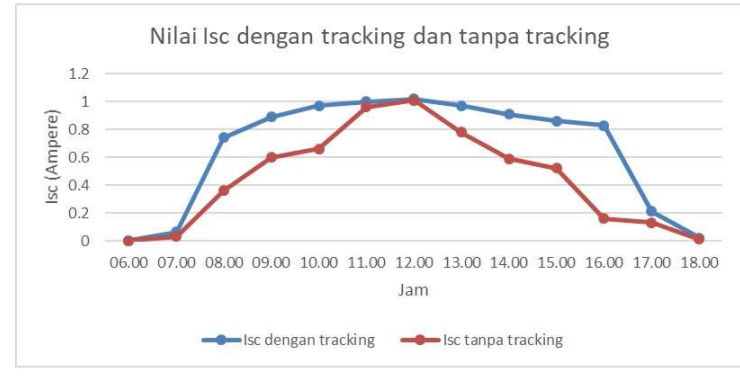

Gambar 11. Grafik perbandingan nilai Isc dengan tracking dan tanpa tracking

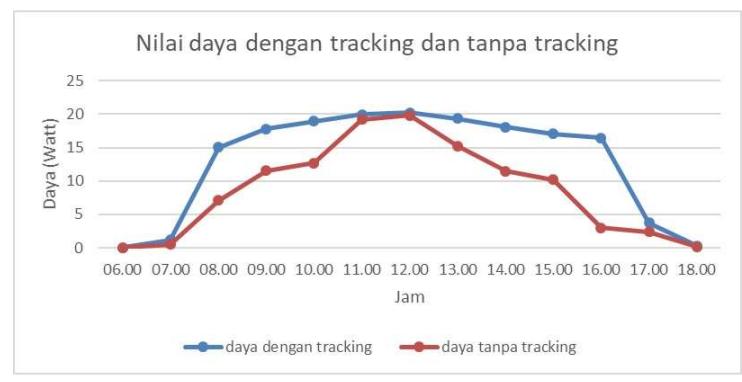

Gambar 12. Grafik perbandingan nilai daya dengan tracking dan tanpa tracking

\section{KESIMPULAN}

Dari hasil perancangan, pembuatan alat serta pengujian alat tracking cahaya matahari yang telah dilakukan dapat disimpulkan bahwa alat tracking cahaya matahari pada photovoltaic jenis satu sumbu horizontal yang telah dibuat ini telah dapat memposisikan penampang modul solar cell mengikuti gerak semu harian matahari dari timur ke barat mendekati tegak lurus dengan sudut datang cahaya matahari dengan rata-rata penyimpangan dari posisi tegak lurus sebesar $5^{\circ}$.
Penggunaan tracking tidak begitu mempengaruhi nilai tegangan, tetapi lebih meningkatkan nilai arus sehingga daya yang dihasilkan juga lebih meningkat. Berdasarkan pembahasan sebelumnya telah dihitung nilai daya yang dihasilkan tanpa tracking adalah 8,71 Watt, sedangkan dengan menggunakan alat tracking meningkat menjadi 12,46 Watt. Terdapat peningkatan sebesar 3,75 Watt kemudian dikurangi dengan konsumsi daya untuk motor sebesar 2,08 Watt sehingga penggunaan alat tracking ini dapat meningkatkan daya keluaran solar cell sebesar 1,67 Watt.

\section{DAfTAR PUStaka}

[1] Mostavan, A. (2000). Catatan Kuliah Energi Surya. Bandung: ITB.

[2] Yuwono, B. (2005). Optimalisasi Panel Sel Surya dengan Menggunakan Sistem Pelacak Berbasis Mikrokontroller AT89C51. Surakarta: Universitas Sebelas Maret.

[3] Tudorache, T., \& Kreindler, L. (2010). Design of a Solar Tracker System for PV Power Plants. Acta Polytechinca Hingarica, Vol.7 No. 1.

[4] Prinsloo, G., \& Dobson, R. (2015). Solar Tracking. South Africa: Stellenbosch University.

[5] Dhanabal, R, et al. (2013). Comparison of Efficiencies of Solar Tracker Systems with Static Panel Single-Axis Tracking System and Dual-Axis Tracking System with Fixed Mount. International Journal of Engineering and Technology (IJET), Vol. 5 No.2 Apr - May 2013.

\section{Biodata Penulis}

Dwiprima Elvanny Myori, lahir di Palembang 1 November 1988. Mengikuti pendidikan S1 Matematika Universitas Andalas pada tahun 2006 hingga 2010, dan melanjutkan pendidikan S2 Matematika Universitas Andalas pada tahun 2010 hingga 2012. Sejak tahun 2012 menjadi dosen tetap di jurusan Teknik Elektro Fakultas Teknik Universitas Negeri Padang hingga sekarang.

Riki Mukhaiyar, lahir pada 25 Juni 1978 di Padang, menyelesaikan pendidikan doktoral di University of Newcastle Upon Tyne pada tahun 2015. Sejak tahun 2008 menjadi dosen tetap di jurusan Teknik Elektro Fakultas Teknik Universitas Negeri Padang hingga sekarang.

Erna Fitri, mengikuti pendidikan Diploma IV Teknik Elektro Industri jurusan Teknik Elektro FT UNP pada tahun 2013 hingga 2017. 